\title{
Materializing Virtues: Crafted Miniatures as Moral Examples in the Argentinean Andes
}

OLIVIA ANGÉ, Sociology of Development and Change Group, Wageningen University, 1 Hollandseweg, 6706 KN Wageningen, The Netherlands.Email: Olivia.Ange@wur.nl

In the Argentinean Andes, people craft miniatures in order to please Saint Anne. Most literature on Andean miniatures focuses on their exchange and use. This paper addresses their production process in an attempt to show that the value of miniatures is entangled in practices. Ethnographic description shows that miniatures should please the saint because they are said to be much more complicated to craft than their normally scaled homologues, and thus their production requires more diligence and faith. In this light, it is argued that miniatures are more than a physical reproduction of a larger-scaled model; they are examples in the sense that they completely incarnate key moral values. Yet, their coexistence with industrially manufactured items accounts for the exercise of individual choice in the realization of ritual scaling practices. In the context of an ongoing ethical turn in anthropology, this paper explores the articulation of collective morality and freedom as it relates to ritual scaling practices. In so doing it also highlights the entangled transmission process of technical skills, religiosity, and morality.

Key words: miniatures, labor, ritual, values, social transmission, Andes, Feast of Saint Anne

Tributes to virgins and patron saints are key moments in the Andean ritual calendar. Likewise, Kolla people in the Argentinean Andes honor Catholic figures year-round with processions, ecclesiastical rites, civic speeches, feasts, and balls. In the Valley of Humahuaca, Argentina, Saint Anne's feast day on July 26 is a highlight, with a multitude of miniature fairs being organized as part of her celebration. People congregate in churches and houses hosting her statue, happily circulating a wide array of miniature objects (food, utensils, fabrics, decorations, and toys). Elsewhere (Angé n.d.) I have described the exchanges in which these miniatures are involved, highlighting their participation in a complex transactional system involving different entities and fields of action.

In this paper I want to look at the production process of miniatures. This topic remains largely untouched in the literature on Andean miniatures, which usually focuses on their exchange and use (e.g., Allen 1997; Golte and Gabriel 2014; Molinié 2012; Sillar 2012). Still, the importance of considering miniatures within their

Published online: October 25, 2016

Journal of Anthropological Research (Winter 2016). (C2016 by The University of New Mexico. All rights reserved. 0091-7710/2016/7204-00XX\$10.00 
production context has been demonstrated, notably by archaeologist Sheila Kohring in an important paper on miniature crafting, where she stated that "understanding how miniatures are produced allows significant insight into perceived use and importance in the society, as it provides an understanding of their conceptualisation and categorisation" (2011:41). Indeed, looking at the crafting of Saint Anne miniatures highlights that miniatures' values are entangled in practices. This ethnography thereby supports David Graeber's anthropological theory of value, in which he advanced that "what is ultimately being evaluated are not things, but actions" (2001:49).

Interestingly, people consider the very act of crafting miniatures as a way of giving tribute to Saint Anne because she is held to have transmitted her outstanding skills to human artisans. When exploring the fabric of miniatures, the question of transmission is thus fundamental. As Michael Herzfeld (2004) pointed out, understanding practical epistemology actually requires considering the wider social context in which transmission unfolds. In his book on the transmission of artisanship in a Greek island, he provides a very rich description of how hierarchies of value are conveyed by the transmission of body skills, thereby demonstrating that "apprenticeship is less concerned with the transmission of craft techniques than with modeling the social values and attitudes within which the craft is practiced" (2004:51). In this vein, I want to question how crafting participates in the construction of social personae, in the particular context of miniature production.

Ethnographic description of the Saint Anne celebration clearly shows that miniature production participates in the transmission of moral values. ${ }^{1}$ In a paper concerned with identifying an "ontological home for values," Joel Robbins indicated that values take real existence in examples understood as "a mode of real existence of value" (2015:28). He thereby departed from the perspective of seeing values as ideal forms and emphasized their realization in facts. In this light, saints such as Anne epitomize such exemplary realization of value. In this paper, I explore how objects can be appreciated as instantiation of such exemplary figures. For this purpose, I demonstrate that Saint Anne's miniatures are more than physical representations of larger originals: they are exemplary realizations of moral values, which, as I further argue, are entangled with their producer's subjectivity.

To support my argument, I draw on Nancy Munn's use of the concept of qualisign in her landmark study of value transformation in Papua New Guinea (1986). She elaborated on Charles Pierce's phenomenological philosophy in which qualisigns refer to embodied qualities imbued with values in a given social context. This concept helps us to understand how smallness is culturally constructed as a desirable quality that reflects the artisan's subjective values. In this vein, I look at smallness as qualia. Qualia is another key concept in Pierce's theory of human experiences in the world, referring to abstract properties as embodied in concrete entities. This philosophical notion was brought into the anthropological purview by Lily Hope Chumley 
and Nicholas Harkness (2013). They use this notion "to refer methodologically to the experience of qualities as a fact of sociocultural life, rather than to qualities as purported properties of things in the world" (2013:3). When looking at qualia as experienced in Andean scaling practices, I want to tease out how values are incarnated and, in this process, culturally constructed as collective models for human actions.

Considering miniatures as examples thus enlightens how miniatures participate in the creation of shared values in Andean societies, thereby addressing the key question of this special issue of $J A R$ concerned with the complex web of relationships clustered around miniatures. In addition to providing an account of the emergence of order in social life, regarding miniatures as examples also accounts of the space left for change and the experience of individual choice. This study of Saint Anne miniatures thus addresses a question that has been at the core of an "ethical turn" in anthropology since the publication of James Laidlaw's seminal article (2002).

To develop my argument on the role of miniatures in the creation of social values, I draw on ethnographic data from the Saint Anne celebration in the town of Humahuaca. I lived in the Argentinean Andes for more than six years, between 2005 and 2013. In July 2013 and 2014, I participated in several fairs, where I sold tiny clay pots I had bought at the market. From the many events I attended, both in town and in surrounding rural communities, I have chosen to describe here the main fair in Humahuaca, where stalls display the widest array of industrial and handcrafted miniatures. I was surprised to hear it said by a native of Humahuaca nicknamed Gringo, in an allusion to his white skin, that miniature fairs are a "matter of country people" even though the best-attended fairs take place in town. In the next section, I sketch the complex and shifting social identity of Saint Anne devotees in an attempt to explain why scaling practices are associated with indigenous rural communities.

\section{PEOPLE, SAINTS, AND ECONOMIC RESOURCES IN HUMAHUACA}

Humahuaca is a small town located in the eponymous valley, in the northern Argentinean province of Jujuy, at almost $3000 \mathrm{~m}$ above sea level. Its population numbered some 10,000 inhabitants according to the 2010 provincial census. ${ }^{2}$ However, the town is constantly growing, primarily as migrants arrive from surrounding rural communities in search of a better living and modern facilities. In this South Andean region, the majority of rural villages are registered as belonging to the Kolla Indigenous People. Numbering some 70,500 citizens, Kolla people are the second-largest of the thirty native ethnic groups whose existence was officially recognized by constitutional amendment in 1994, subsequent to acceptance of the International Labor Organization Convention 169 on Indigenous and Tribal Peoples. This contrasts with the Argentinean category of creoles, who are not immediate descendants of Europeans and do not self-identify as indigenous, even if some of their ancestors may have done so (Sturzenegger-Benoist 2006). 
In a region where indigeneity is associated with the country and agricultural exploitation, ethnic identities are particularly blurred in the urban context since people can stress either indigenous or creole filiation, depending on the social setting. In the Cordillera of Jujuy, the constitutional amendment in favor of indigenous peoples has launched a "re-ethnicization" movement, as it is locally known, in which urban people who do not belong to any rural community identify themselves as Kollahighlighting a filiation with indigenous ancestors. Furthermore, indigenous people in the department of Humahuaca are now officially recognized by the state as a distinct ethnic group, the Omaguacas. This reappraisal of indigeneity has been particularly strong in the Humahuaca Valley since it was declared a UNESCO World Heritage site in 2003. The local diffusion of a global hierarchy of value fostered by international heritagization (Herzfeld 2004) involved a reversal of the symbolic appreciation of indigenous people, now publically displayed as a cultural emblem of the nation while remaining politically and economically disadvantaged. A polemic arose over the fact that the richness of the heritage was seen to belong to indigenous people whereas the benefits of the highly lucrative touristic market fueled by UNESCO's prestigious label were monopolized by non-indigenous citizensmostly white and creole migrants from the south of the country.

In this somewhat prolific economic context, some indigenous people who have settled in town make a living from informal street businesses (selling souvenirs, cooking food, driving taxis), while others, more successful, run established businesses or work in hotels and restaurants or as public employees. Many of them maintain strong ties with their home communities, where some still cultivate their plots. Doña Cruz, for instance, brought up nine children in the town of Humahuaca, where she was able to build a house. Yet she still plants maize, beans, and potatoes in her home village, some fifty kilometers away. Even though they maintain some relationship with their rural land, migrants' dependence on the market to provide staples and other necessary goods increases as they settle in town.

Interactions with the virgins and saints are seen as having an enduring impact on people's economic prosperity. Festivals organized for the saints are intended to express people's faith and respect so as to establish an auspicious interaction with these nonhuman agents. Among these saints, Anne is preeminently worshiped in the valley. Identified as the Virgin of Work, she is seen as a key partner for achieving economic endeavors. When I asked worshippers who she is, I heard many different stories. In all of them, Saint Anne, identified as Jesus' grandmother, was a hardworking woman who knitted clothes for the poor or for Jesus when he was a child. Guillermo, the retired son-in-law of the owner of an important statue of her in the town, described her this way:

Saint Anne was a very hardworking woman. She [happens] to be Jesus' grandmother. At this time, she [personally] worked. And she was a woman like us, 
very humble, very poor but she used to work. And, well, she used to do what we are doing now; but she became a goddess.

Accordingly, Saint Anne is now known as the workers' guardian. In the words of Sofia, who organizes another important fair, the saint provides "enthusiasm to keep on working."

Even though she is identified as Jesus' grandmother, Saint Anne is nonetheless seen as a virgin. In this sense, she is an emanation of the Virgin Mary, like the multitude of virgins worshiped in the region (Virgen de Candelaria, Virgen de Punta Coral, Virgen de Guadalupe, Virgen del Rosario, etc.). As I was told by Cristina Lopez, organizer of the main fair in town: "The Virgin is one, she just has different names." Some even associate the Virgin with Pachamama (Mother Earth), as did a middle-aged woman selling clay pots in a market, who described Pachamama as "the Virgin of the earth" (see also Derks et al. 2012:199; Harris 2000:202). This identification is supported by the motherhood with which they are both imbued when they are called Mother (Madre). However, I have also heard people make a clear distinction between the chthonic existence of Pachamama and the celestial existence of the saints, who are portrayed as intermediaries between humans and God. While Pachamama is seen as having primary responsibility for the growth and reproduction of all entities in the environment, including humans, Saint Anne is the one who provides strength and luck ( fuerza and suerte in the Spanish spoken in the Argentinean Cordillera) so they can make a living. Both are thus seen as being responsible for the distribution of human vitality, in its various dimensions. This is a potential they share with unsanctified ancestors, who are also honored as a source of vitality, as is usual throughout the Andean Cordillera (Harris 2000:28).

Next, I take a closer look at the fairs with which worshippers give tribute to Saint Anne.

\section{SAINT ANNE'S CELEBRATION IN THE LOPEZ FAMILY}

The fair convened by the Lopez family is described as the main festival by people in Humahuaca. The Lopez family is said to have been the first in the town to celebrate Saint Anne. Their statue stands in the chapel of the family estate on the outskirts of Humahuaca, along with other images, such as Saint Roque and Saint James the Apostle (Santiago; Figure 1). The whole family gathers to celebrate these saints' feast days. Most come all the way from San Salvador de Jujuy, where they have moved. Organizing these celebrations not only honors the saints; the feasts are also intended to show reverence for the ancestors who built the chapel to express their deep faith in these Catholic figures. Failure to celebrate a saint following the ancestors' customs would have damaging consequences. A daughter of the elderly Doña Lopez, owner of the chapel, was afraid that the ancestors might get upset if she did not respect the exact date of the celebration. She warned me: "If we don't do it, [elders who have 


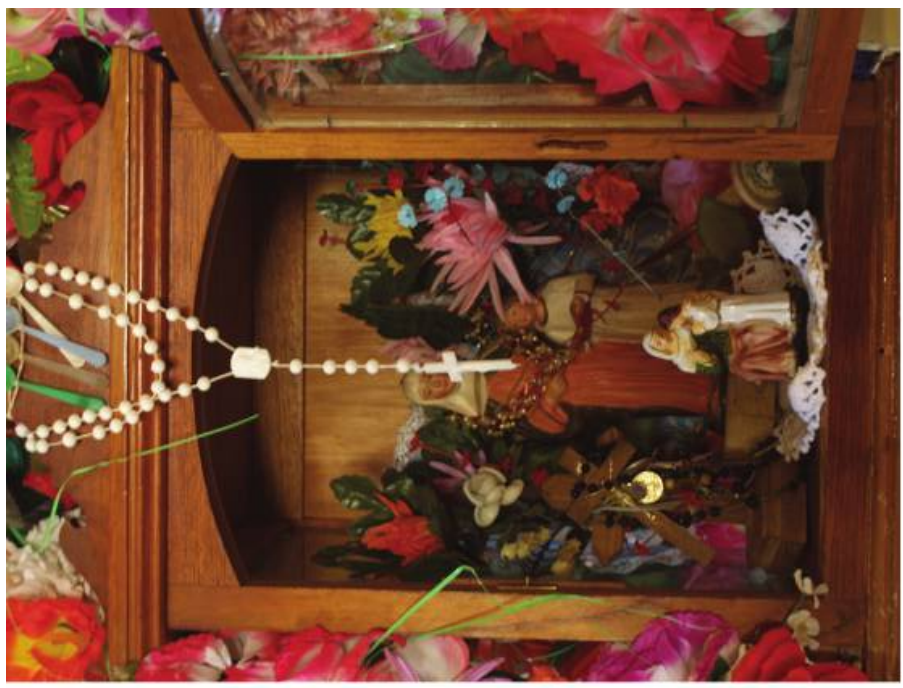

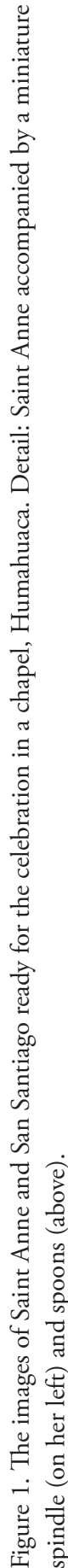

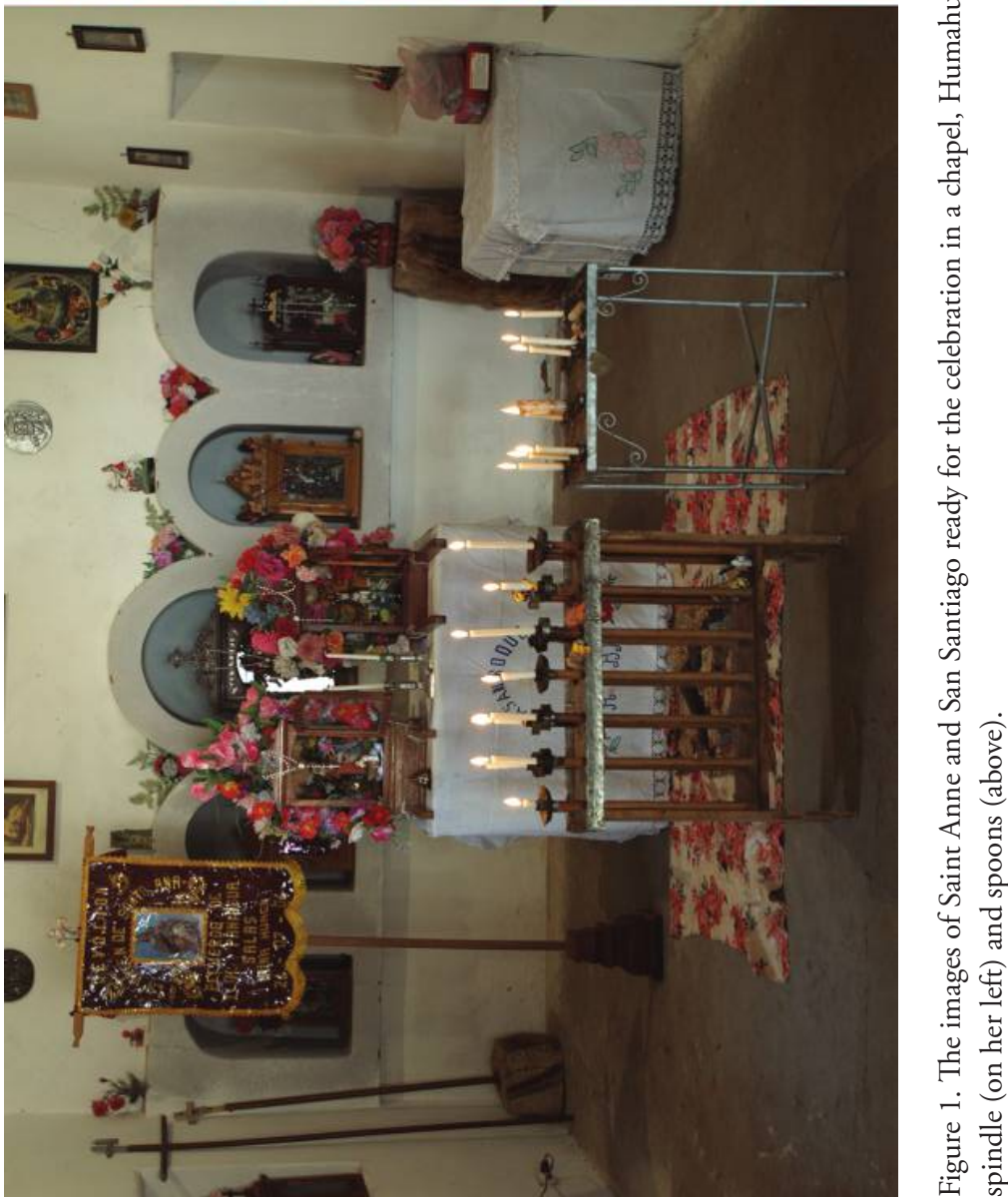

This content downloaded from 193.052.023.174 on November 11, 2016 07:50:25 AM All use subject to University of Chicago Press Terms and Conditions (http://www.journals.uchicago.edu/t-and-c). 
died] will castigate us. . . . their body is [bodies are] not here anymore, but their spirit does [is] and they can get upset."

On July 26, people congregate in their courtyards to celebrate Saint Anne. Public announcements are made on local radio stations, although all Humahuaqueños are aware of the festival, as many of them are active devotees of the Virgin. In 2013, I arrived at the Lopez family home at noon, bringing a bag of miniature clay pots I intended to sell. The members of the family, who had been working intensively during the preceding days, were still busy with preparations. This involved cleaning the chapel, cooking food to be sold to the visitors, installing the loudspeakers and other infrastructure. The few people who had already arrived were regular traders (comerciantes) who intended to set up their stalls at the same strategic places they occupy every year; I was kindly (but firmly) told to leave these areas free. Other traders arrived later, by mid-afternoon, along with visitors eager to look at the small objects on sale. That year, the fair drew several hundreds of buyers and some fifty traders. All were women, ${ }^{3}$ although some were helped by a son or husband.

The majority of the stalls were stocked with ready-to-eat food served in small portions: cakes, pies (empanadas), sandwiches, breads, donuts, jelly, stuffed cornhusks (tamales), etc. The woman next to me was selling a range of miniature knitted textiles she had carefully pinned on a white lace background (Figure 2). Nowa-

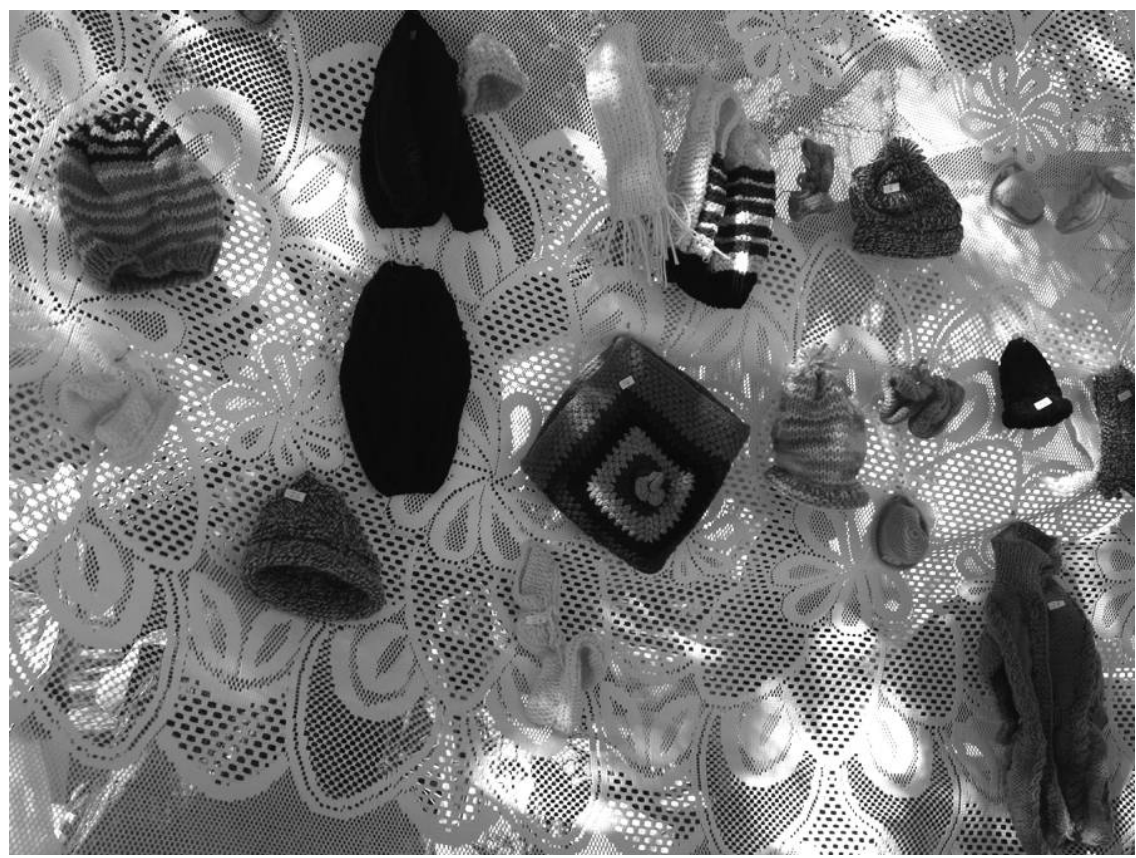

Figure 2. Knitted miniature clothes on sale at Saint Anne's fair. 
days, knitted work is the main handicraft available. According to the participants, the range of handcrafted miniatures used to be much wider. In the "olden days," shoemakers used to provide rubber sandals, carpenters would bring small pieces of furniture, scrap dealers would craft agricultural tools, and so on. Alejandra, who is one of the organizers, nostalgically remembered: "It used to be beautiful, the tools they used to craft: spades, wheelbarrows, identical to the big ones. And the furniture, properly crafted, with leather seats set in the wood. And with carving and everything!" Her recollection highlights the appreciation of details in the crafting of miniatures; these details involve producing contrasts by bringing together an array of colors, materials, and patterns replicating the larger original.

Saint Anne's Day miniatures also feature factory-made goods, which, according to the participants, are recent additions. These include foods (candies, popcorn, beer, lemonade, etc.), toys (small cars, dolls, playing cards, etc.) or housewares (drinking glasses, garlic graters, thread, hair clips, etc.). Some of these manufactured items are produced in the thriving Bolivian economy of alasitas. ${ }^{4}$ Others are usual commodities not produced as miniatures but selected by the traders for their small size. As Cristina (Alejandra's sister) noted: "Nowadays, because everything has changed, they buy things and they resell them. Other people sell their handicraft. These are not the times of yesterday. Before, we used to craft everything." Most stands mix industrial commodities with some handcrafted pieces (Figure 3). The coexistence of industrial and handcrafted items, displaying a wide array of materials, precision, and scales, attests to the room for individual creativity in the constitution of the stall's contents.

Nostalgic tropes also deplore the diffusion of new modalities of miniature exchanges. According to the participants, miniatures used to be swapped through barter. Others remember that until the second half of the twentieth century, miniatures were exclusively exchanged for Saint Anne bills (plata de Santa Ana)—scraps of paper stamped by the organizers. Still in use in other fairs in the town, they usually have an established parity with the peso, ${ }^{5}$ but in some rural communities they don't, which significantly modifies the functioning of the fair (Angé n.d.). In Humahuaca, miniatures are now usually sold for Argentinean pesos. Each seller is free to set the price she expects her goods to fetch. The prices of miniatures are set according to the formal market. Craftspeople figure out a price that will cover the cost of the raw material but which also depends on the quantity of labor required to produce it; others make comparisons with normally scaled objects. As for food, buying in miniature is a bit more expensive than the same quantity of ingredients served in normally scaled portions. For instance, a woman who usually sells cookies at the bus station at 4 pesos each sold one-fifth-sized pieces for 1 peso at Saint Anne's fair in 2013.

Before purchasing miniatures, the newcomers usually walk to the altar to "greet the Virgin" (saludar a la Virgen). At three o'clock, most of the participants had arrived, and the chapel was crowded. Using a microphone, an organizer invited everyone to gather around the statue to offer some prayers. Before the fair was officially 


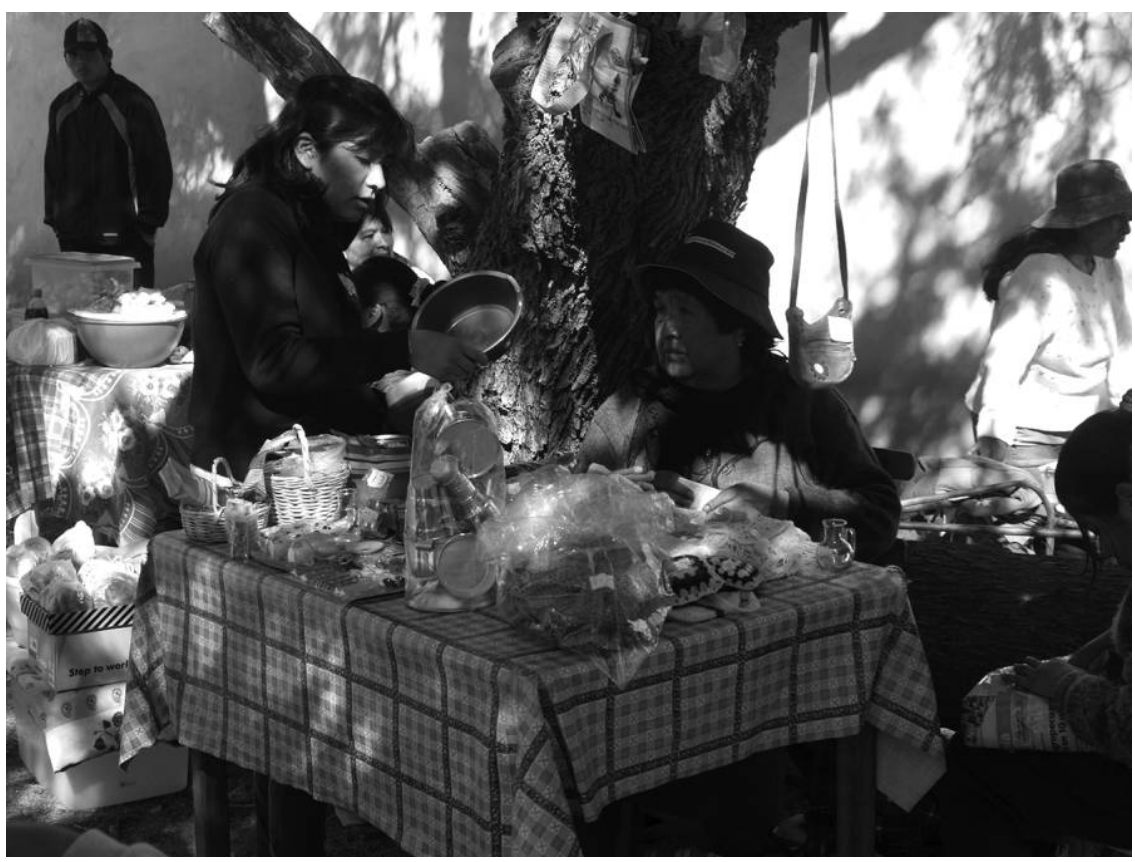

Figure 3. Saint Anne devotees selling a mix of handcrafted and factory-made miniatures at a fair, Humahuaca.

opened, the worshippers took the saint out for a procession around the courtyard, burning incense all around. This is how Eugenia described the proceedings:

First comes the procession: they walk around the courtyard. And then, they say: "OK, let's start Saint Anne's party." And all the movement, like [ants moving around] an anthill. They all want to sell, they all provide an array of things, they display all they have. Before the procession, some might sell secretly, but after the procession, (the fair) is launched.

After the procession, when the signal had been given for the fair to open, the hustle and bustle became intense indeed. People happily bought, admired, ate, and handled miniatures accompanied by the sound of cumbia and folksongs broadcast by loudspeakers (Figure 4).

As exchanges thrived, people ate and drank at the tables set up in an adjacent courtyard, where traditional dishes were served for 50 soles a dish. ${ }^{6}$ Others started playing taba, placing bets with oranges in a throwing game displaying dexterity. Games are common features of Saint Anne's Day parties. ${ }^{7}$ As usual during the saint's feast day, the afternoon passed in an atmosphere of fun, heightened by the joys of consumption. Foodstuffs were ingested in small serving sizes, without ever 


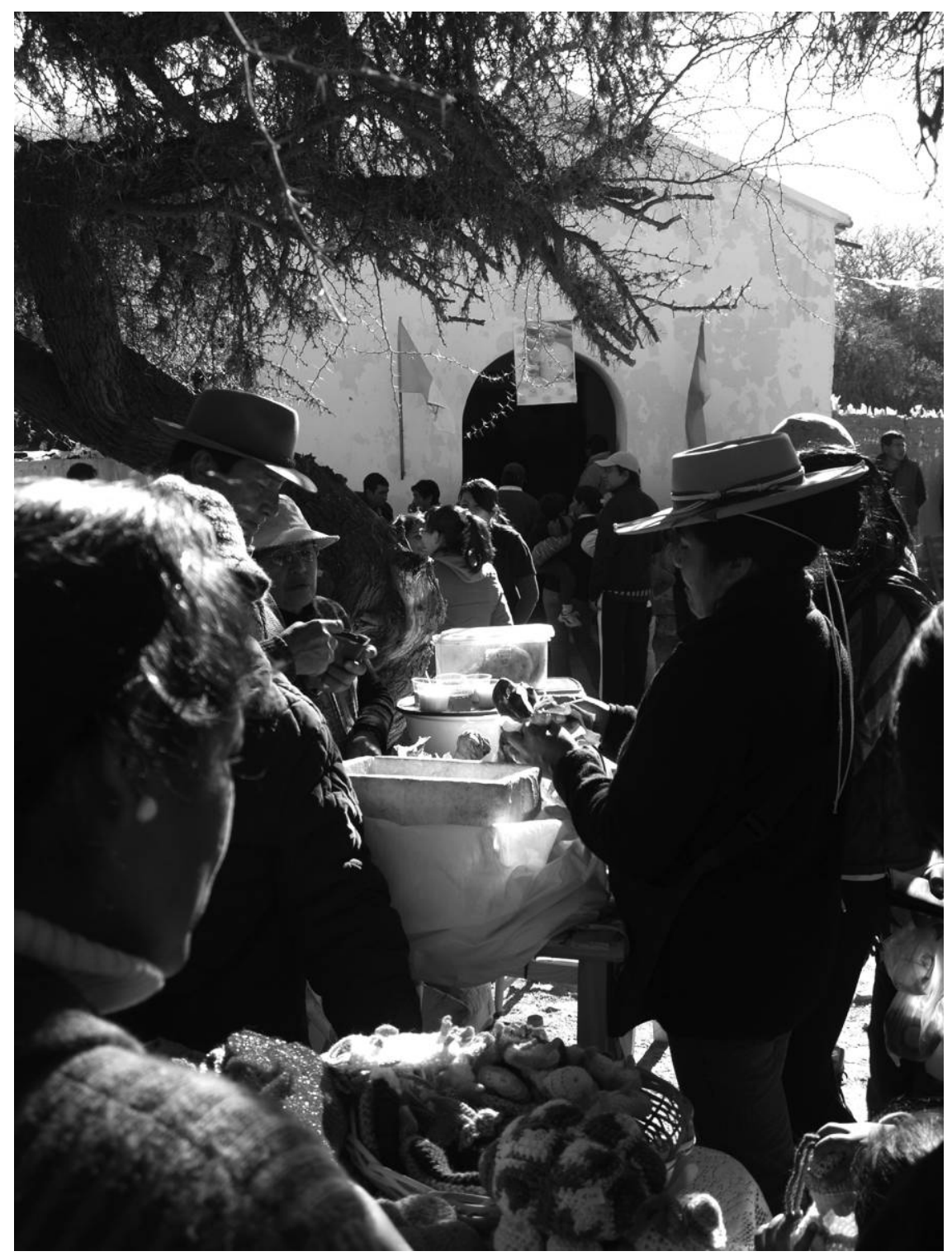

Figure 4. Fair in front of a chapel.

constituting a proper meal. Most small objects were purchased as toys (Figure 5) and subsequently mistreated by children, which would considerably reduce their lifespan. However some miniatures are intended to be kept. Some people bring their acquisitions back home and conserve them carefully as mementos of the Virgin and her fair (Figure 6). 


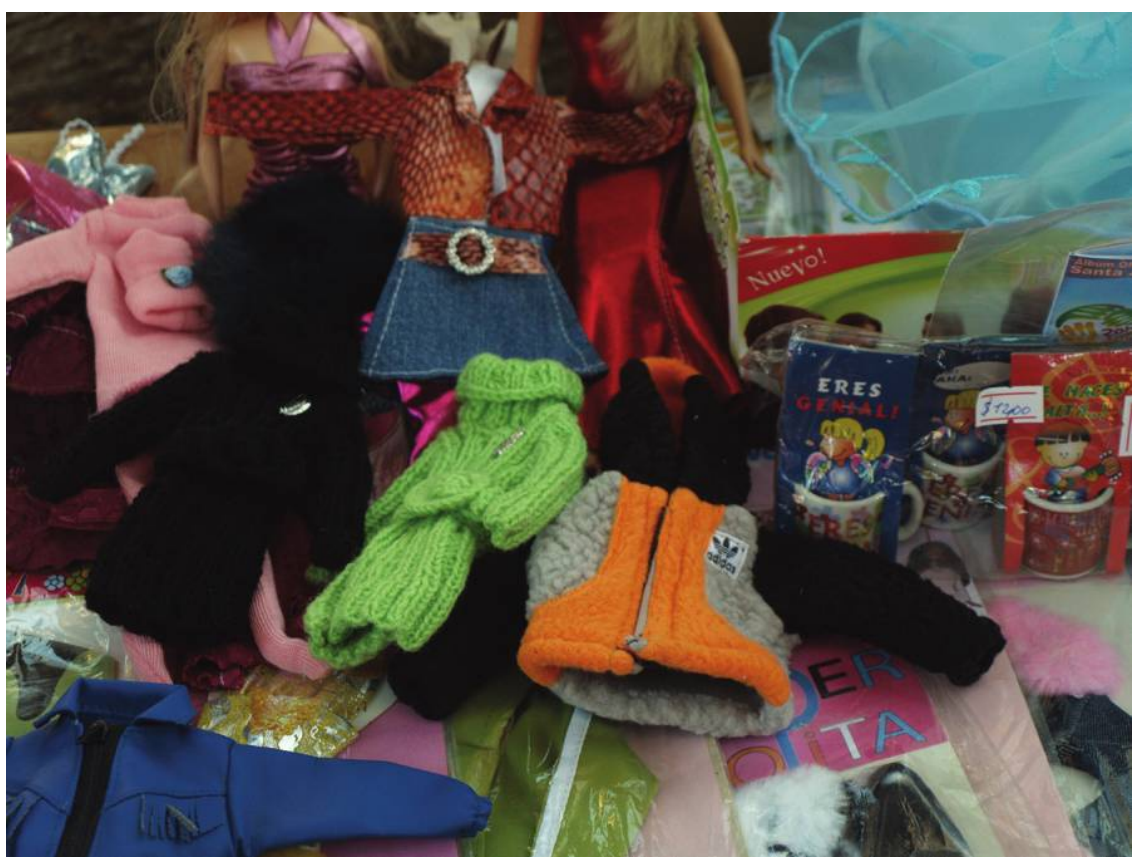

Figure 5. Handcrafted and manufactured miniatures intended to be used as toys.

I agree with Kohring that "the symbolic use of these objects, representational or non-representational, begins with the choices producers make during the production process, which characterises them as special, enchanted, or ritually charged" (2011:34). Yet the biography of these small handcrafted pieces is not determined by the production process. Miniatures that have been crafted with faith and diligence may be used as toys or lost without major concern, while unsophisticated items, or industrial ones, can be as treasured as "golden rings," according to worshippers' metaphor. Saint Anne's miniatures can thus be charged with or devoid of cosmological potential at any time in their social life. The following section is concerned with the way handcrafted miniatures are constructed as examples encapsulating social values during their production process.

\section{PLEASING THE SAINT BY CHANGING THE SCALE}

Even as pilgrims' exchanges and consumption trigger tangible joy among the participants, they all agree that miniatures are first intended to please Saint Anne. In so doing, the worshippers hope that she will grant them luck and strength, intangible resources that are fundamental for human production and reproduction but over which they have only minor control. Whether used up instantaneously or kept as precious items, miniatures are intended for the saint: "They are for the Virgin," 


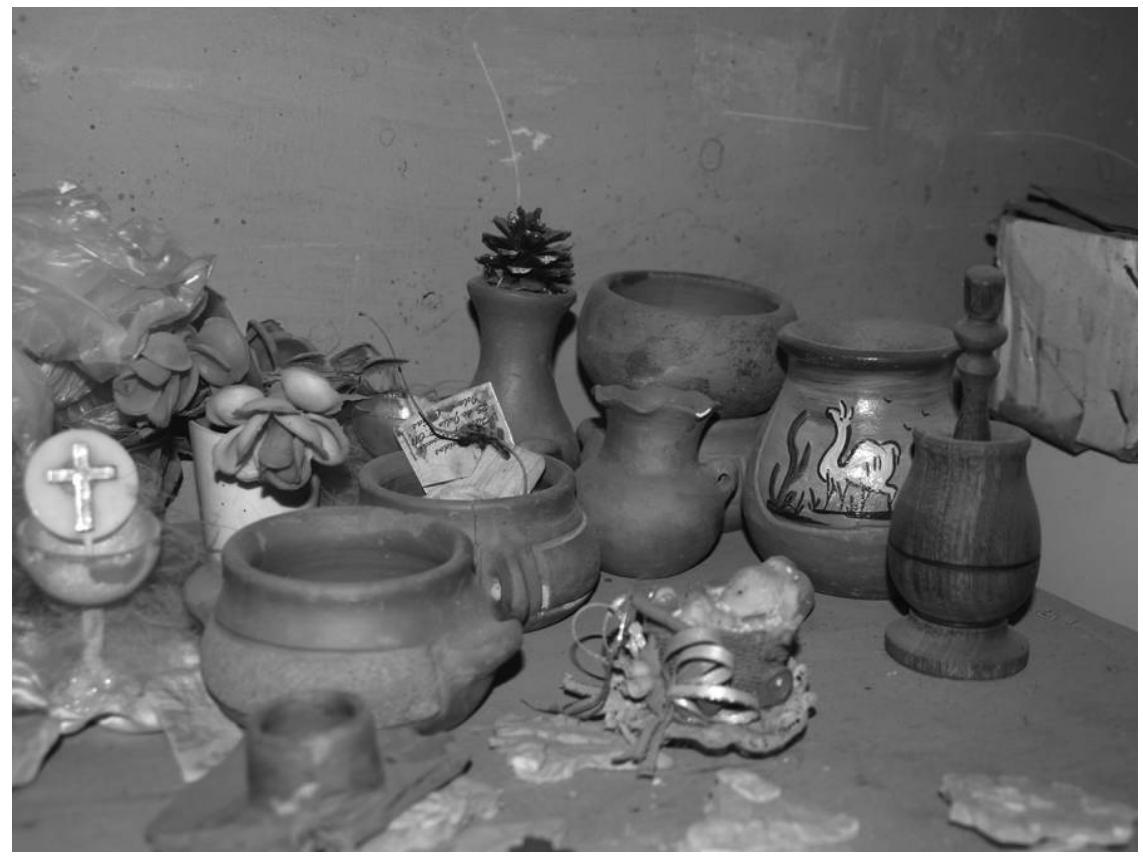

Figure 6. Miniature utensils stored as mementos on top of a cupboard in a devotee's kitchen.

traders and consumers alike underscore. This is attested by the elders' instruction to store miniatures under the Virgin's altar before they are exchanged. In the community of Rodero, boxes filled with small goods are piled up in the church, where they remain during the mass and procession (Figure 7). Peddlers only pick them up in the afternoon, before the last procession, which brings the Virgin to the church's court, where the fair takes place. From then on, the miniatures are considered to be blessed and therefore appreciated as conveyors of Saint Anne's cosmological force. As noted above, at the Lopez family celebration, exchanges are prohibited before the saint has been prayed to and the procession is completed. This underscores the fact that miniatures are addressed to the Virgin before being circulated among human beings.

When I asked participants why offerings to Saint Anne needed to be small, they consistently replied: "Because it's for the little Saint Anne, of course," as if it were selfevident. People at fairs seemed to greatly appreciate the small objects themselves, as attested by their marveling faces and comments when looking at a reproduction of an object they usually see in its actual size. "Very little, really beautiful!" (Chiquitito, bien bonito!), they would say with a loving expression. This aesthetic appreciation, generalized by Lévi-Strauss as "émotion esthétique très profonde" (1962:37), is projected on the Virgin, who, it is believed, would also experience the visual pleasure of the small objects. 


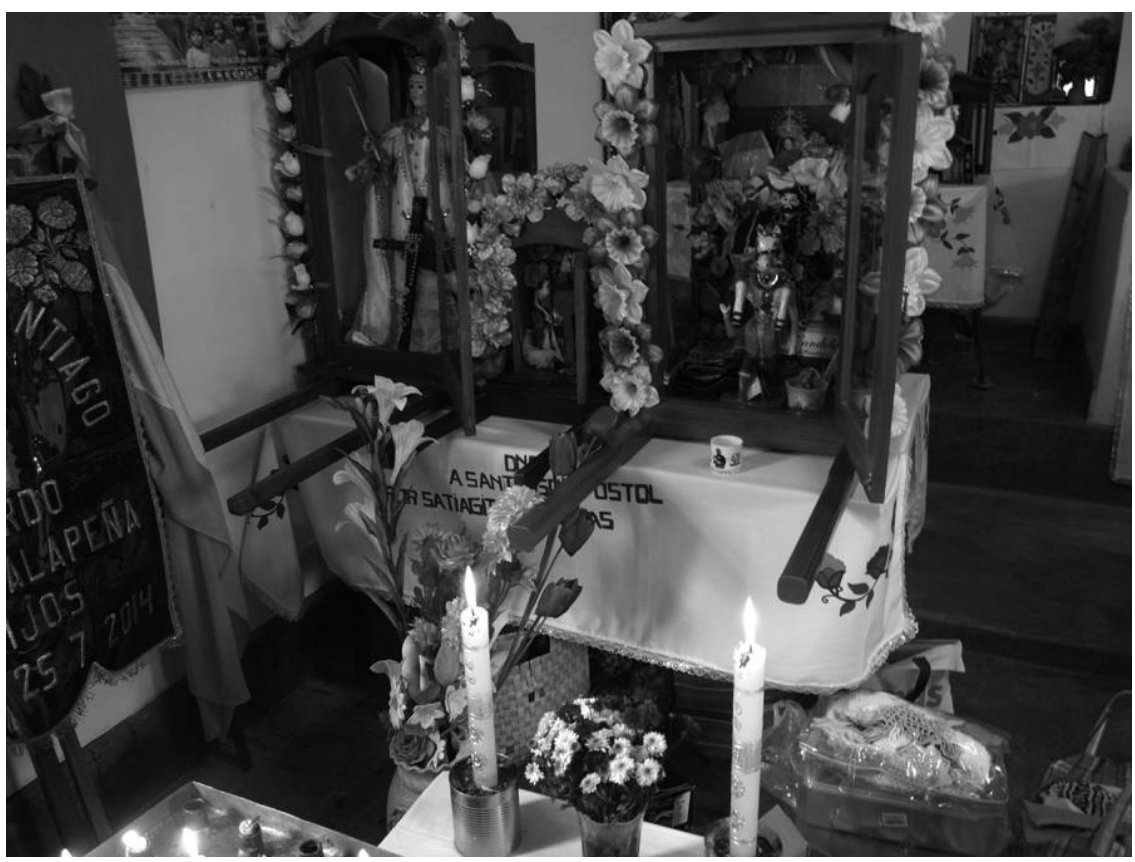

Figure 7. Miniatures stored underneath the altar before the fair starts in the community of Rodero.

In the case of handcrafted miniatures, these esthetic qualities are an outcome of crafting gestures that are appreciated for themselves. Saint Anne is expected to be particularly pleased by tiny handcrafted items, people say, because they display the fruits of an ability that she is believed to have transmitted. As the Virgin of Work, she provides her worshippers with the skills and diligence necessary for achieving their professional ambitions. This is the way Eulogia, a woman aged about fifty, explained her yearly participation in a fair in Humahuaca: "It seems that she gave me this ability. I come to thank her. I knit the whole year round thinking of the Virgin, of what I am going to knit for her. And then I come here, and I leave happy." Craftspeople agree about the increased dexterity required for producing small pieces, as compared with normal ones. This common feature in miniature crafting (Foxhall 2015; Kohring 2011; Stewart 1992) here takes on particular meaning since the strength and skills to perform this work are regarded as being distributed by the saint. Hence, crafting miniatures involving meticulous and long work displays extraordinary zeal as a manifestation of the talent Saint Anne has granted. As Doña Cruz's daughter Sofia put it, in a discourse that explicitly posits creative labor as a key value:

My grandfather used to say that we must value work, making things, taking your time. Because it takes times to make the very small things. It is not the 
same as making them large. It is much more difficult, much more laborious and much more complicated.

Miniatures are then offered to the saint as the materialization of increased zeal and skills devoted to the production of objects that will not be used for functional purposes. Most utensils lose their usefulness at a reduced scale, and small dishes of food do not nurture hungry people. In fact, the Lopez family has now opted to serve their food on normal plates because, as Eugenia acknowledged, the miniature portions her family used to sell in the patio adjacent to the fair did not satiate their guests. In addition, instead of being used by adults, many small items are intended for children to play with.

Functionality is not of concern for those who produce miniatures. Their intention is to please Saint Anne instead, by manifesting the values for which she has been sanctified as the Virgin of Work. ${ }^{8}$ Instead of using their skill for their own benefit, miniature crafters use their skills to please the saint. In this sense, producing miniatures is also the materialization of faith. This is attested by the stance of devotion miniature crafters are expected to take. Sofia explained how this moral prescription was explicitly transmitted to her by her grandmother:

It mostly is the faith we put into these tiny things. I don't know, my grandmother always instructed me, and she told me this: "If we do something, we must do it with affection. Do it with enthusiasm because we do it for Saint Anne. She was Jesus' grandmother. She was a person who was very hardworking," she used to say.

Producing miniatures in the context of Saint Anne's feast day is indeed described by her worshipers as a practical expression of faith. "All this, is to believe in God. Nothing else," concluded Guillermo after listing all the activities involved in celebrating Saint Anne. As pointed out by David Berliner and Ramon Sarro in their book on Learning Religion (2007), although recent cognitive approaches have provided important insights on how faith is mentally constructed, we still know very little about the religious transmission process as it unfolds in the interplay of social interaction. Here, the process of crafting the material world provides the context in which religious stances are experienced thus showing how the learning of faith and skills intertwine in this Andean context.

In this light, the smallness of a miniature is not only admired for its aesthetic attributes. It is appreciated as the material expression of its crafter's aptitude to exercise physical work both skillfully and diligently - a potential that is realized with the strength of life distributed by the saint. In a fascinating paper on ritual drinking of soyu in South Korea, Nicolas Harkness showed how the qualia of softness as materialized in this drink merges gustative and social appreciation. This appreciation, he concluded, "links consumers to culturally valorized, highly gendered, and temporally positioned identities within contemporary Korean society” (2013:28). 
In a similar vein, the qualia of smallness, as experienced in miniatures, is associated with a positive value combining sensual and moral appreciations, where the social value results from the fact that smallness in handcrafted items instantiates strength in life.

Even though making miniatures continues to be described as a particularly complex and elaborate craft, thus requiring increased vitality, it has actually become unusual to see miniatures crafted with all the details mentioned by nostalgic persons. When it comes to knitting, for instance, women use factory-made yarn instead of wool they have carded, spun, and dyed themselves. The patterns are also very basic. These pieces are nonetheless acknowledged by the worshippers as propitious offerings to the Virgin, as are industrial products requiring no artisanal skills at all. In the next section, I address the introduction of pieces whose production does not fully materialize labor and vitality, thereby showing how the experience of smallness, and its relation to strength, is historically situated.

\section{THE TRANSMISSION OF MORAL VALUES AND PERSONAL CREATIVITY}

As mentioned above, miniatures are not only given as a gesture of gratitude for blessings received in past undertakings, they also act as a petition for further support. When offering miniatures, worshippers are mainly asking for good luck. The saint is also seen as a fundamental source of skill and cleverness to craft artifacts, and to engage in productive ventures more generally. Yet another highly cherished value workers are looking for is strength, which is a vital force enabling one to perform an activity with assiduity and perseverance. They ask for energy to learn and produce without becoming bored or tired before they finish their task. When addressing adroitly produced miniatures with faith and enthusiasm, worshippers thus expect to be granted luck and strength when engaging in everyday economic activities.

Similar to the Mexican offerings studied by Perig Pitrou (2015, 2016), Saint Anne's miniatures are meant to establish a regime of co-activity with nonhuman entities, in an attempt to enhance human productivity by synchronizing their efforts with divine intervention. Here, miniaturized production displays what humans will do in daily life: they will objectify physical labor in artifacts and they will foster their joyful circulation. As the presages of a flourishing daily economy, the production of handcrafted miniatures enacts a mutual commitment between humans and the saint, the former promising skillful and conscientious labor and the latter promising luck and vitality. At the end of the cycle, both sides have circulated what the other is lacking: people please the saint with the most beautiful objectification of their work, and the saint pleases the former with luck and strength.

Yet through this interaction, people do more than craft their surrounding material world, they also construct their subjectivities as hardworking and faithful people. When laboriously producing miniatures, humans perform the same gestures that Anne would have mastered when she was alive. They become skillful artisans 
similar to her in virtue. Eugenia Lopez made it clear when recalling the origin of the celebration in their family:

My parents were very good Catholics. They thus created a chapel and they put there an image of Saint Anne. They taught us when we were kids that Saint Anne was a very hardworking woman; and that whoever did the play of Saint Anne [see n. 7] would be likewise. We then dedicate ourselves to making things in miniature.

Thus, Saint Anne is not only an exemplary figure for mastering body skills, she also serves as an inspiring example if one intends to stand out as a hardworking person. Co-activity in this case is not only about the synchronization of technical practices; it also conveys an ethical moral posture that would make humans and the saint similar in virtue.

Still, scaling practices for the Saint Anne feast day are not strictly driven by the reproduction of Anne's example, as attested by the multiplication of industrial goods in the fairs' stalls. The invasion of industrial goods is seen as a trend toward laziness, as compared with the diligence for which the elders — and the Virgin—are admired. When I asked Doña Cruz, who organizes another important fair in Humahuaca, why she was not producing miniatures anymore, she replied in a resigned tone: "But we are lazy, the people of these days." Nevertheless, most worshippers see industrial items as suitable gifts for the saint as well, as long as they respect the prescribed reduced scale. Displaying a beautifully furnished stall with a wide array of colorful miniatures also prompts admiration. Being able to supply a diversity of commodities is seen as a labor-intensive achievement as well. This is attested by the widely appreciated participation of Doña Isabela at the fair in the village of Santa Ana. Her neighbors remember with admiration the packets of sugar and flour, seed potatoes, shots of beer, candies, and other tiny commodities she sold for Saint Anne's money. The success of her flourishing store is collectively attributed to Isabela's noticeable participation in the fair.

Isabela used to participate in the fair every year. Yet, in 2014, she just came to purchase miniatures but did not bring anything. She told me when I visited her at her grocery earlier in the morning that she was too tired to prepare a stall because she had been dancing all night to celebrate the Pachamama at a neighbor's place. She insisted that preparing a stall for Saint Anne was quite laborious. I heard this as a way of justifying the incorporation of industrial commodities, not necessarily as a manifestation of modern-day people becoming lazy.

Even if factory-made goods are accepted, a pervasive nostalgia for the days when all the miniatures were handcrafted shows that they are more appreciated than manufactured ones. The fact that most clients asked me whether I had made the clay pots myself confirms that the artisanal process is important to them, even if not compulsory. When instantiated in mass-produced objects, the qualia of smallness 
is severed from the producers' identity since it is not indexed to the same value of skilled and diligent work. That a stall filled with industrial pieces is to a much lesser extent an expression of the seller's vitality might explain why, even though industrial pieces are legion, their trader's stalls usually also feature some handmade pieces. For instance, a young mother who was selling many kinds of plastic toys at the Lopez fair also offered up a series of handmade mini soccer players' images, provided with an accordingly scaled album to stick them in.

In his paper on examples, Robbins argues that some rituals constitute a "key social form in which exemplary representations of values are made socially available" (2015:18). Clearly, the production of miniatures offers a space where worshippers intensely realize the value of labor. Still, the coexistence of handcrafted miniatures with a wide gamut of industrial items on stalls at Saint Anne's fairs points to a more nuanced experience of value during this particular ritual, leaving room for personal choice between different kinds of scaling practices. Thus, my ethnographic data show that ritual can also serve as a space for negotiating how to realize values properly. The new turn given to the celebration of Saint Anne illustrates a concrete setting where the tensions provoked by the emergence of new spaces for the expression of personal freedom can be grasped. Nostalgic tropes for diverse, fine handcrafted pieces highlight an ethical controversy around the participation in market economies where value production is not necessarily enmeshed with labor. I even met a worshipper who decided not to participate in the fair anymore, contending that it has become a business and is inappropriate for giving tribute to the saint. The facts that the bestattended fairs feature a gamut of commodities, and that most stalls mix industrial and handcrafted pieces, attest to a certain acceptance of manufactured miniatures.

\section{CONCLUSION: SCALE PRACTICES AND}

THE PRODUCTION OF HARDWORKING PEOPLE

I have demonstrated how the act of crafting miniatures, through embodied skills that have been transmitted from the Virgin and other ancestors, establishes an intimate connection to these nonhuman beings. This connection is created by performing similar gestures, not simply as a mirror representation but as a way of making both subjectivities similar in virtues. These choreographies indeed realize invisible human values as hardworking, skillful workers, thus identical with Anne before she was sanctified and with elders who were devoted to her. Here we clearly see how crafting miniatures conveys a "moral economy of concrete labor" (Comaroff and Comaroff 2005:181), which should ideally buttress trade. Such a relation between the crafting of selves and the crafting of objects is more than analogical (Herzfeld 2004:38); it is consubstantial in the sense that they take part in the same material process. As a result, miniatures are appreciated as tokens (sensu Graeber 2001) of human creative practices.

Like the identification made by Munn between the lightness of a canoe and the lightness of human bodies in Gawa, I have pointed out an indexicality between the 
strength of life embodied in handmade miniatures and the strength of the body that produces them. In her fieldwork in Oceania, Munn identifies directionality and spatiality as clusters on which the construction of qualisigns articulates. The study of miniatures suggests that dimensionality expressed in the contrasted qualities of smallness and grandeur constitutes another potential cluster of value creation. Dimensionality thus serves as an axis where strength is constructed as a key qualisign in Kolla society. This study further suggests that an object serves as an example when it appears as an iconic index of a collectively appreciated value. If we agree with Robbins that ritual serves as an example in that it realizes value in an extraordinary way, we understand why miniatures are so prone to be used in such contexts: they intervene outstanding instantiations of positive qualisigns of value.

Yet the Saint Anne celebration still leaves room for "lazy people" and their marketing of industrial items. The constant evolution of miniature fairs, now integrating official money and increasingly incorporating manufactured pieces, calls forth consideration of individual creativity in the way people are inspired by Saint Anne's example. Clearly the ritual here is not only a locus for the strict reproduction of the social order but is also a social ground for ethics negotiation in the context of an indigenous society that becomes increasingly involved in the global hierarchy of value. Because it leaves room for the expression of individual judgment, ritual miniature production contributes to the construction of ethical subjects who are able to actualize virtues and to discern the suitable application of moral prescriptions in any given situation (Faubion 2011; Laidlaw 2002; Robbins 2012).

Robbins (2015) has pointed out that people are not expected to enact ritual values with the same integrity in their everyday life. As for the case at hand, people are not expected to produce miniatures, and the laborious effort they require, in their quotidian economy. Yet, what they are expected to extend to their daily life is the very articulation between profitable trade and the intrinsic value of creative labor as displayed in the ritual space-time. Clearly, the construction of the ethical self through material production is intended to expand beyond the ritual setting: when producing miniatures for the fair, worshippers hope that they will be granted increased skills and strength to work intensively the entire year.

When looking at what is actually conveyed by miniature crafting, I have argued that changes in scale also serve as a locus for the social construction of faith. Delving into miniature practices highlights the importance of materialities and embodiment in the construction of religious persons. This material exploration of Andean Catholic faith enlightens a local cosmology of body strength as circulated within a network of human and nonhuman beings. In this cosmological configuration, the saint conflates with the elders: both are involved in the transmission of craft skills, both are expected to be pleased by miniature production, and both are considered as exemplary representations available to human beings in their process of ethical self-crafting.

This brings us to the core concerns of this special issue of JAR dealing with the social and cosmological relationships in which miniatures are embedded. Indeed, 
this Andean case demonstrates how miniature crafting delineates indigenous belonging by stressing worshippers' imagined descendancy from common ancestors, and by realizing a social hierarchy of value that distinguish them from the Argentinean national economy, driven by neoliberal market ideology.

\section{NOTES}

My first thought goes to all the devotees of Saint Anne in Humahuaca, who gave me the opportunity to enjoy the delight of circulating and consuming miniatures in 2013 and 2014. This research was carried out during a postdoctoral fellowship at the Musée du Quai Branly. I am most thankful to the Département de Recherche for supporting my work, both intellectually and financially. In particular, I am grateful to Julien Clément, Jessica de Largy Healy, Frédéric Keck, Paz Nunez-Regueiro, and Anne Christine Taylor. At the Departmental Seminar, I have received generous and insightful comments from Perig Pitrou and Giovanni da Col. I wish to express further gratitude to David Berliner, Marco Di Nunzio, Laurent Legrain, Pierre Petit, and Denis Regnier for their rich discussion of an earlier version of this text at the University of Brussels. I finally thank Lawrence Guy Straus and two anonymous reviewers for their interest in my manuscript and the insightful comments they provided. Of course, any remaining errors are mine. (Names in text are pseudonyms.)

1. It is interesting to note that Mireia Lopez-Bertran and Jaime Vives-Ferrandiz come to similar conclusions in their archaeological study of miniatures from domestic contexts in Iron Age Iberia. Relating the presence of small potteries and tools to the emergence of complex institutions and social hierarchy, they argue that "these objects were used as a means of enculturation and for the learning of values and norms" (2015:80). However, the archaeological data do not allow for in-depth elaboration on the social transmission of value in this context.

2. Source: http://www.dipec.jujuy.gov.ar/dc_datoscensales.html (accessed in March 2016).

3. This fact raises important questions on gender, related to the predominance of women in Andean markets. I will not address this question here since it would require a whole other article.

4. Alasitas are miniatures sold during pilgrimage, mostly in Peru and Bolivia, to be used as votive gifts to a Virgin (see Allen 2016; Golte and Gabriel 2014; Molinié 2012).

5. Buyers exchange pesos for stamped bills at the entrance to the fair in order to purchase goods. When leaving the fair, they can exchange any unused ritual money for official currency. A commission of 10 to $20 \%$ is retained by the organizers for each transaction. According to them, the money earned "is for the Virgin" since, in principle, it is used to enliven her celebration by providing maize beer and other foods for the participants.

6. This was worth approximately 5 euros at the time, which is the price of a basic menu in a restaurant in town. 
7. The fair is regarded as entertainment for the young and old alike. "Play Saint Anne" (jugar a la Santa Ana) are the words used by the participants to refer to their transactions. Situated at the crossroads of ritual, play, and mundane economic practices, this fair raises fascinating questions about the intertwining of these modes of action. I will not address this issue further, since it falls outside the scope of this paper.

8. In fairs such as the one described here, where miniatures are sold for pesos, some crafters of miniatures are also motivated by the money they are able to earn. This quest for money generates an ethical controversy that goes hand in hand with the one regarding the proliferation of mass-produced items. This entanglement between religious and monetary values is an important question that I address in Angé n.d.

\section{REFERENCES CITED}

Allen, Catherine. 1997. "When pebbles move mountains: Iconicity and symbolism in Quechua ritual," in Creating context in Andean culture. Edited by R. Howard-Malverde, pp. 73-84. Oxford: Oxford University Press.

2016. The living ones: Miniatures and animation in the Andes. Journal of Anthropological Research 72(4):00-00.

Angé, Olivia. n.d. Reproductive commodities. Faith, happiness and prosperity in the Argentinean Andes. Ethnos, under review.

Berliner, David, and Ramon Sarro. 2007. "On learning religion: An introduction," in Learning religion: Anthropological approaches. Edited by D. Berliner and R. Sarro, pp. 1-19. Oxford: Berghahn Books.

Chumley, Lily Hope and Nicholas Harkness. 2013. Introduction: Qualia. Anthropological Theory $13(1 / 2): 3-11$

Comaroff, Jean, and John Comaroff. 2005. "Millennial capitalism and the culture of neoliberalism," in The anthropology of development and globalization. Edited by M. Edelman M. and A. Haugerud, pp. 177-87. Oxford: Blackwell.

Derks, Sanne, Willy Jansen, and Catrien Notermans. 2012. "Miniatures and stones in the spiritual economy of the Virgin of Urkupiña in Bolivia," in Things: Religion and the question of materiality. Edited by B. Meyer and D. Houtman, pp. 198-211. New York: Fordham University Press.

Faubion, James. 2011. An anthropology of ethics. Cambridge: Cambridge University Press.

Foxhall, Lin. 2015. Introduction: Miniaturization. World Archaeology 47 (1):1-5.

Golte, Jürgen, and Doris L. Gabriel. 2014. Alasitas: Discursos, prácticas y simbolos de un "liberalismo aymara altiplánico" entre la población de origen migrante en Lima. Lima: Fondo Editorial del Instituto de Estudios Peruanos.

Graeber, David. 2001. Toward an anthropological theory of value: The false coin of our own dreams. New York: Palgrave.

Harkness, Nicholas. 2013. Softer soyu in South Korea. Anthropological Theory 13 (1/2):12-30.

Harris, Olivia. 2000. To make the earth bear fruits: Ethnographic essays on fertility, work and gender in highland Bolivia. London: Institute of Latin American Studies. 
Herzfeld, Michael. 2004. The body impolitic: Artisans and artifice in the global hierarchy of value. Chicago: University of Chicago Press.

Kohring, Sheila. 2011. Bodily skill and the aesthetics of miniaturisation. Pallas 86:31-50.

Laidlaw, James. 2002. For an anthropology of ethics and freedom. Lournal of the Roval Anthropolooical Institute 8(2):310-32.

Lévi-Strauss, Claude. 1962. La pensée sauvage. Paris: Plon.

Lopez-Bertran, Mireia, and Jaime Vives-Ferrandiz. 2015. Miniatures from domestic contexts in Iron Age Iberia. World Archaeoloogy 47(1):80-93.

Molinié, Antoinette. 2012. "L'argent sauvage: Une énigme andine de la monnaie," in Monnaie antique, monnaie moderne, monnaie d'ailleurs . . Métissage et hybridations. Edited by P. Pion and B. Formoso, pp. 175-87. Paris: Editions De Boccard.

Munn, Nancy. 1986. The fame of Gawa: A symbolic study of value transformation in a Massim (Papua New Guinea) society. Cambridge: Cambridge University Press.

Pitrou, Perig. 2015. Life as a process of making in the Mixe highlands (Oaxaca, Mexico): Towards a "general pragmatics" of life. Iournal of the Roval Anthropological Institute 21(1):85-105.

2016. Co-activity in Mesoamerica and in the Andes. Journal of Anthropological Research 72(4):00-00.

Robbins, Joel. 2012. On becoming ethical subjects: Freedom, constraint, and the anthropology of morality. Anthropology of This Century 5. Available online at http://aotcpress.com /articles/ethical-subjects-freedom-constraint-anthropology-morality/

2015. Ritual, value, and example: On the perfection of cultural representations. Lournal of the Roval Anthropological Institute 21(1):18-29.

Sillar, Bill. 2012. Patrimoine vivant: Les illas et conopas des foyer andins. Techniques et Culture 58:66-81.

Stewart, Susan. 1992. On longing: Narratives of the miniature, the gigantic, the souvenir, the collection. Durham, NC: Duke University Press.

Sturzenegger-Benoist, Odile. 2006. L’Argentine. Paris: Karthala. 